\title{
SIMPÓSIO SOBRE O PROJETO DO CÓDIGO CIVIL
}

\section{OS RELATÓRIOS APROVADOS NO CERTAME PROMOVIDO PELA ASSOCIAÇÃO DOS MAGISTRADOS BRASILEIROS}

No período de 1 a 5 de dezembro de 1975, na cidade do Rio de Janeiro, sob os auspícios da Associação dos Magistrados Brasileiros e sob a presidência do desembargador Luiz Henrique Steele FiIho, do Tribunal de Justiça daquele Estado, foi realizado o Simpósio Sobre o Projeto do Código Civil, ora em tramitação no Congresso Nacional.

Dividiram-se os trabalhos em duas etapas distintas, a saber: na primeira, pronunciaram conferências os coautores do anteprojeto, professores Miguel Reale; Ministro José Carlos Moreira Alves, do Supremo Tribunal Federal; Sylvio Marcondes; Clóvis do Couto e Silva e Torquato de Castro, que dissertaram sobre as matérias que Ihes couberam orientar na preparação de nossa futura codificação civil como membros da Comissão Elaboradora e Revisora designada pelo Governo Federal. Falou, ainda, o professor Caio Mario da Silva Pereira, presidente da Ordem dos Advogados do Brasil. O desembargador Ebert Chamoun, também integrante da Comissão Elaboradora e Revisora, compareceu a um dos grupos de estudo, para dar esclarecimentos aos participantes do Simpósio. Na segunda etapa ou fase dos trabalhos, foram organizadas seis Comissões, para exame do Projeto em todos os seus aspectos, e designados os respectivos presidentes e relatores.

Os relatórios dessas Comissões foram apreciados em plenário, rendo sido aprovados com pequenas modificações, conforme assinala - relatório-geral apresentado na sessão de encerramento pelo juiz Sérgio Mariano, do Tribunal de Alçada do Estado do Rio de Ja. neiro.

A sessão de encerramento foi presidida, em sua primeira fase 
destinada à apreciação do relatório-geral fundado nos relatórios parciais com as sugestões ou propostas de lavra das Comissões, pelo desembargador Oscar Tenório, Reitor da Universidade do Estado do Rio de Janeiro, que destacou, na ocasião, o papel do Poder Judiciário na estrutura orgânica do Estado e a relevante e espinhosa missão do juiz. Ao Ministro Luiz Gallotti, ex-presidente do Supremo Tribunal Federal, coube presidir à solenidade de entrega de várias honrarias, outorgadas a personalidades com destacados serviços à magistratura e à sociedade em geral. Falou, saudando os homenageados, - juiz Miranda Rosa, do Tribunal de Alçada do Estado do Rio de Janeiro e da Diretoria da Associação dos Magistrados Brasileiros. Usou da palavra o Ministro Rodrigues Alckmin, que foi agraciado com a "Cruz do Mérito Judiciário".

Todos os trabalhos do Simpósio tiveram lugar no Palácio da Justiça, nas instalações dos Tribunais de Justiça e I Alçada do Rio de Janeiro, graças ao apoio dos respectivos presidentes desembargador Luís Antonio de Andrade e Juiz Fabiano de Barros Franco.

Damos a seguir os relatórios e as conclusões das várias Comissões que estudaram as matérias disciplinadas no Projeto do Código Civil, atualmente na Câmara dos Deputados, onde recebeu mais de mil emendas.

\section{1.' COMISSÃO}

\section{PARTE GERAL}

Reuniu-se a Comissão com a presença dos seguintes membros: Ministro Renato Machado, do Superior Tribunal do Trabalho; desembargador José Pessoa de Oliveira Cavalcanti, do Tribunal de Justiça de Pernambuco; professor Hamilton Xavier, da Universidade Fedoral Fluminense e juiz Geraldo Arruda Guerreiro, do Primeiro Tribunal de Alçada do Estado do Rio de Janeiro. Por consenso unânime dos demais, foi eleito presidente o Ministro Renato Machado, sendo relator, por designação do presidente da Associação dos Magistrados, o juiz Geraldo Arruda Guerreiro. Foram relatadas, debatidas e votadas as proposições a seguir relacionadas.

I - Do desembargador José Pessoa de Oliveira Cavalcanti:

$1.0^{\circ}$ Que se excluísse do art. 24, par. 2. ${ }^{\circ}$, relativo à curadoria dos bens do ausente, a preferência em razão do sexo.

Votação: Aprovada por unanimidade, sendo que o Ministro Renato Machado apresentava proposição idêntica. 
$2^{\circ}{ }^{\circ}$ Que fosse definido, com maior precisão quantitativa, 0 conceito de desproporcionalidade caracterizador de lesão (art. 155).

Votação: Aprovada por unanimidade, havendo proposição idêntica do Ministro Renato Machado.

3.) Que se alterasse a redação do art. 26, item, 1, de modo a não se considerar interessado para requerer a sucessão provisória - cônjuge separado de fato há mais de cinco anos, em harmonia com o art. 1.877.

Votação: Não aprovada, por ausência de maioria, vencido o proponente.

II - Do Ministro Renato Machado:

$1 .^{\circ}$ Que fosse alterado 0 art. $5 .^{\circ}$, para conceder a maioridade aos 18 anos, e, também, para abranger a hipótese de emprego público sob o regime de FGTS.

Vołação: Não aprovada, por ausência de maioria, vencidos o proponente e o juiz Geraldo Arruda Guerreiro.

$\left.2 .^{\circ}\right)$ Que o art. 28, relativo à conservação do valor da herança, fosse alterado para permitir a conversão também em tí́ulos de empresas públicas da União.

Vołação: Aprovada por unanimidade.

3. $\left.{ }^{\circ}\right)$ Que o art. 29, relativo às garantias do herdeiro para se imitir na posse dos bens do ausente, incluísse a fiança bancária.

Votação: Aprovada, por maioria, vencido o des. José Pessoa de Oliveira Cavalcanti.

4..$^{\circ}$ Que 0 art. $7 .^{\circ}$, inciso 11 , relativo à morte presumida, incluísse a hipótese de desaparecimento do não combatente, em virfude de guerra.

Votação: Aprovada, por unanimidade.

5. ${ }^{\circ}$ Que o art. 13 tivesse a seguinte redação: "Os atos de disposição do próprio corpo são permitidos livremente, exceto se conirariarem os bons costumes".

Votação: Não aprovada, por maioria, vencido o proponente.

6.) Que fosse alterada a redação do art. 124, para maior clareza.

Votação: Aprovada, por maioria, vencido o juiz Geraldo Arruda Guerreiro. 
7.') Que o art. 130, relativo a prazos, fosse alterado para manter, integralmente, a disciplina do art. $184, \S 2 .^{\circ}$, do Código de Processo Civil, quanto ao termo inicial coincidente com feriado.

Vołação: Aprovada, por unanimidade.

8. ${ }^{\circ}$ Que fosse dada melhor definição quantitativa ao dano considerável resultante da coação (art. 149).

Votação: Aprovada, por unanimidade.

9.॰) Que a simulação (art. 165) fosse considerada motivo de anulabilidade, não de nulidade.

Votação: Aprovada, por maioria, vencido o juiz Geraldo Arruda Guerreiro. 184).

10. ${ }^{\circ}$ Que fosse excluída a indenização por dano moral (art.

Votação: Não aprovada, por ausência de maioria, vencidos o proponente e o professor Hamilton Xavier.

11..$^{\circ}$ Que no art. 212 fosse incluído o dolo como motivo de revógação da confissão, em consonância com o Código de Processo Civil.

Votação: Aprovada, por maioria, vencido o desembargador José Pessoa de Oliveira Cavalcanti.

12..) Que no art. 213, relativo à escritura pública, fosse excluída a menção a prova plena.

Votação: Aprovada, por unanimidade.

13.०) Que no art. 214 fosse excluída a parte final, relativa ao conserto dos traslados por outro escrivão.

Votação: Aprovada, por unanimidade.

$\left.14 .^{\circ}\right)$ Que os arts. 225,226 e 227 , relativos às provas, fossem alterados para manter a sistemática dos artigos 401, 402, 405 e 406 do Código de Processo Civil.

Vołação: Aprovada, por unanimidade.

15. ) Que se expressasse o aplauso da comissão ao restabelecimento do instituto da lesão, às inovações do art. 165, inciiso III, e ałt. 166, relativos às nulidades, à distinção explícita entre prescrição e decadência, ao art. 188, relativo à preșcrição de exceção, ao art. 192, em face, do art. 219, 5. do Códgio de Processo Civil, ao art. 
200, relativo à interrupção de perscrição, e aos artigos 229 e 230, relativos às hipóteses de recusa a exame médico.

Vołação: Aprovada, por unanimidade.

III - Do juiz Geraldo Arruda Guerreiro:

1.) Que se acrescentasse o seguinte parágrafo único ao art. 184: "Salvo se a prova ou as circunstâncias indicarem o contrário, presumir-se-á a culpa do causador do dano".

Votação: Aprovada, por unanimidade.

$2^{\circ},^{\circ}$ Que se alterasse e se aditasse o art. 180: "Invalidado ○ negócio jurídico, restituir-se-ão as partes e terceiros ao estado em que antes dele se achavam, e, não sendo possível restituí-los, serão indenizados com o equiválente.

Parágrafo único. Pelo valor da indenização que the couber em face do contraente beneficiado pelo reconhecimento da invalidade (art. 184), o terceiro de boa fé poderá exercer o direito de retenção".

Votação: Aprovada, por unanimidade.

3..$^{\circ}$ Que a regra do art. 188 fosse estendida aos casos de decadência, tendo em vista, principalmente, as hipóteses de anulabilidade, dando-se a seguinte redação ao art. 206: "Aplica-se à decadência o disposto nos artigos 188, 193 e 196, I.

Votação: Aprovada, por unanimidade.

\section{(aa) Ministro Renato Machaduo}

(Presidente) - T. S. Trabalho - D.F.

\section{Juiz Geraldo Guerreiro}

(Relator) - Juiz T. A. - Rio de Janeiro

\section{Des. José Maria de Queiroz}

(T. J. - Ceará)

Des. José Pessoa de Oliveira Cavalcanti

(T. J. Pernambuco)

Prof. Hamilton Xavier

(U. F. Fluminense) - Rio de Janeiro 


\section{2." COMISSÃO}

\section{OBRIGAÇÕES}

Reuniu-se a Comissão com a presença dos seguintes membros: Juiz TOMAZ GOMES CAMPELO, do Piauí; Juiz ILMAR NASCIMENTO GALVÃO, do Acre; Juiz FRANCISCO JOSÉ LUTZEMBERGER, do Rio de Janeiro; Professor PAULO CEZAR CHAVES DE ARAGÃO, da Faculdade Gama Filho (Rio de Janeiro) e Juiz NARCIZO A. TEIXEIRA PINTO, do I Tribunal de Alçada do Estado do Rio de Janeiro.

Por votação unânime dos demais, foi eleito presidente o Juiz TOMAZ GOMES CAMPELO, funcionando como relator, por designação do Presidente da Associação dos Magistrados Brasileiros, o Juiz NARCIZO A. TEIXEIRA PINTO.

Os trabalhos desenvolveram-se em três sessões, tendo sido debatidas, votadas e aprovadas as seguintes proposições:

1 - Por sugestão do Desembargador SAMPAIO DE LACERDA (encaminhada pela Comissão que estuda a "Atividade Negocial"):

Retirar do Projeto o Capítulo XXII do Título VI do Livro I (artigos 866 a 889).

\section{JUSTIFICATIVA:}

Os contratos bancários devem ser tratados em lei especial.

11 - Por sugestão do Professor PAULO CEZAR CHAVES ARAGÃO:

1) $O$ art. 517, em sua parte final, deverá ter a seguinte redação: "... caberá ao expropriado, ou aos seus herdeiros, direito de preferência, pelo preço atual da coisa".

Acrescer-se-ia, assim, uma cláusula final ao artigo seguinte, que passaria a ter a seguinte redação:

Art. 518: "O direito do preferência não se pode ceder nem passa aos herdeiros, ressalvado o disposto no artigo anterior".

\section{JUSTIFICATIVA:}

O art. 517 do Projeto reproduz a norma do art. 1.150 do Código atual, bem como a regra de que o direito de preferência não se pode ceder nem passa aos herdeiros.

Convém, em consequência, para solucionar a questão existente acerca da transmissibilidade causa mortis do direito de preferência não convencional, mas oriundo da destinação do bem expropriado, 
que se dê ao aludido art. 517 uma redação que se concilie com a atual jurisprudência do S.T.F. (ac. in RDA 73/155, entre muitos outros).

2) O Código deverá conter todos os preceitos gerais relativos aos vários títulos de crédito, que incidiriam, caso a caso, no que coubesse, deixando-se para as leis extravagantes apenas a regulamentação dos aspectos particulares dos diversos títulos.

\section{JUSTIFICATIVA:}

Pretende o Projeto, no Título VIII do livro I da Parte Especial (artigos 923 e seguintes), codificar as regras gerais referentes ao direito cambiário. Embora louvável o propósito, mantêm-se ainda fora do texto do Projeto diversas normas relativas à mesma matéria, e de igual cunho genérico, como aquelas pertinentes ao aceite, à multiplicação dos títulos e a vários outros institutos.

3) $\bigcirc \S 3 .^{\circ}$ do art. 797 deverá ter a seguinte redação:

"Intentada a ação contra o segurado, denunciará este a lide ao segurador, quando e como the determinarem as leis do processo".

\section{JUSTIFICATIVA:}

O aludido parágrafo deve ficar em harmonia com o disposto no artigo 70, inciso III, do Código de Processo Civil.

III - Por sugestão do Juiz ILMAR NASCIMENTO GALVÃO:

O artigo 934 deverá ter a seguinte redação: "O aval deve ser dado no próprio título".

\section{JUSTIFICATIVA:}

A expressão "verso e anverso do" afigura-se inútil.

IV - Por sugestão do Juiz FRANCISCO JOSÉ LUTZMBERGER:

1) O PARÁGRAFO ÚNICO do art. 462 deverá ter a seguinte redação:

"O contrato preliminar deverá ser levado a registro para operar seus efeitos a respeito de terceiros".

\section{JUSTIFICATIVA:}

A redação atual poderá levar ao entendimento de que, em qualquer caso, o registro será sempre indispensável.

2) Suprimir o parágrafo único do art. 455. 


\section{JUSTIFICATIVA:}

A norma projetada é heterotópica, eis que é de exclusiva natureza processual, inteiramente disciplinada pelo atual C.P.C.

Rio de Janeiro, Sala da Comissão, em 4 de dezembro de 1975.

A Comissão:

(aa) Juiz Tomaz Gomes Campelo

Presidente (Associação - Piaui)

Juiz Narcizo A. Teixeira Pinto

Relator (T. A. - Rio de Janeiro)

Juiz Ilmar Nascimento Galvão

(T. J. - Acre)

Prof. Francisco José Lutzemberg

(Fac. Estácio de Sá - R. J.)

Prof. Paulo Cezar Chaves de Aragão

(Fac. Gama Filho - R. J.)

\section{3." COMISSÃO}

\section{ATIVIDADE NEGOCIAL}

A Comissão reuniu-se com a presença dos seguintes membros: presidente - des. Ary Florêncio Guimarães (Paraná), escolhido por aclamação; relator - Des. J. C. Sampaio de Lacerda (Rio de Janeiro), designado pela presidência da A.M.B.; e des. Hamilton de Moraes e Barros (Rio de Janeiro); des. Paulo Barbosa Lessa (Rio Grande do Sul); des. Serapião de Aguiar Torres (Sergipe) e Juiz Joaquim Antonio de Vizeu Penalva Santos (Tribunal de Alçada do Rio de Janeiro).

Por unanimidade sugeriu a Comissão as seguintes proposições:

\section{1.` Proposição}

A nomenclatura apropriada para o Título do Livro II do Projeto do Código Civil poderá ser Da Atividade Mercantil, em substituição à constante: "Da Atividade Negocial".

\section{2." Proposição}

A inclusão da disciplina da chamada ATIVIDADE NEGOCIAL, no corpo do Código Civil, não atende quer a considerações de ordem filosófica, quer a motivações de política legislativa ou, sim- 
plesmente, de natureza pragmática. Impôe-se, por consegüinte, a separação desse Livro do Código Civil.

Com a retirada do Capítulo relativo à Sociedade Anônima, por se tratar de matéria em franca evolução, houve substancial esvaziamento do Livro II do Projeto. Os demais institutos que reyulam a atividade mercantil estão também sujeitos a uma constante evolução, e por isso demandam tratamento através de leis especiais.

Sendo assim, a Comissão entendeu que melhor seria expungir do Projeto toda a parte referente à Atividade Mercantil.

\section{3.` Proposição}

Retirar do Projeto o Capítulo XXII, Livro I (artigos 866 a 889), motivado pelo fato de que os contratos bancários deveriam ser objeto de tratamento em lei especial. E consequentemt nte foi remetida a referida proposição à apreciação da Comissão v'e Direito das Obrigações, competente para o exame dessa matéria.

\section{4.' Proposição}

Dar nova redação à parte final do parágrafo único do artigo 1.003 , a fim de torná-la mais clara, tendo em vista a ponátrosa circunstância de que a própria Comissão, no anteprojeto, havia adotado redação mais adequada à definição objetivada.

\section{5. ${ }^{a}$ Proposição}

Alterar o nomen iuris de "sociedade em comum" para "suvicdade com patrimônio comum", como título do Capítulo I, du Subtítulo I, do Livro II, do Projeto. Assim entendeu a Comissão purquanto pareceu mais apropriado o título "sociedade com patrimônio comum", de vez que "os bens e dívidas sociais constituem patrimônio especial, de que os sócios são titulares em comum" (art. 1.025 do Projeto).

\section{6. ${ }^{a}$ Proposição}

O texto do futuro Código Civil, no tocante às sociedades, não deve vincular-se a uma posição radical quanto à natureza jurídica do ato constitutivo das sociedades, em virtude da ampla controvérsia existente sobre a matéria.

\section{7.' Proposição}

O reexame do texto do artigo 1.011 , do Projeto, a respeito da capacidade do empresário e do exercício do comércio pelo seu representante legal, a fim de que seja feita na futura redação da lei 
civil brasileira, na hipótese, uma distinção bem clara entre a situação do menor e a do interdito.

\section{8. ${ }^{a}$ Proposição}

Reexaminar as remissões feitas da aplicação de normas das sociedades simples aos demais tipos societários, adotando-se uma disposição unificada (artigos 1.077, 1.081, 1.090 e 1.121 do Projeto).

\section{9. ' Proposição}

Em face da retirada do Capítulo referente à sociedade anônima, do Projeto, recomendar que o concernente à liquidação das sociedades (artigos 1.136 a 1.146) seja colocado em seguimento à parte que disciplina a dissolução das sociedades (artigos 1.070 a 1.075).

\section{0.' Proposição}

Retirar o vocábulo "Silvícola" do art. 1.007, I, por não se coadunar com a acepção dada pelo art. $3^{\circ}$, item IV, além de ser desnecessário ao bom entendimento do texto.

\section{1. a Proposição}

Dar nova redação ao item II do art. 1.007, a seguir: "o pequeno empresário, considerados los seguintes elementos, isoladamente ou em conjunto":

\section{2." Proposição}

Promover total reexame do Capítulo IV da Seção III, Título IV, Livro II (arts. 1.217 e seguintes), que trata da escrituração, reduzindo essa matéria aos preceitos fundamentais.

\section{3." Proposição}

Reformular o Capítulo VI do Título II, Subtítulo I (arts. 1.124 a 1.126), para, apenas, conceituar a sociedade em comandita por ações, tal como feito em relação à sociedade anônima.

\section{4. ' Proposição}

Substituir o título "Da Sociedade Limitada" para "Sociedade por Quotas de Responsabilidade Limitada" contido no Capítulo IV, do jubtítulo II, do Título II, alterando-se, nos textos pertinentes, a referida denominação.

\section{Proposição}

O Capítulo VII, referente à sociedade cooperativa, ficará resrrito ao seguinte dispositivo: "A sociedade cooperativa reger-se-á 
por legislação especial, aplicando-se-lhe, quando omissa, as disposições referentes à sociedade simples".

\section{Proposição}

A Comissão sublinha a conveniência de a matéria referente às sociedades ligadas (arts. 1.131 a 1.135 do Projeto) ser examinada juntamente com os novos textos de projetos em andamento, pertinentes ao assunto.

Rio de Janeiro, Sala da Comissão, em 3 de dezembro de 1975. A Comissão:

(aa) Des. Ary Florencio Guimarães Presidente

Des. J. C. Sampaio de Lacerda

Relator

Des. Hamilton de Moraes e Barros

Membro

Des. Paulo Barbosa Lessa

Membro

Des. Serapião de Aguiar Torres

Membro

Juiz Joaquim Antonio de Vizeu Penalva Santos Membro

\section{Of. $N .^{\circ} 1 / 75$}

Rio de Janeiro, 3 de dezembro de 1975

Senhor Presidente:

Levo ao conhecimento de V. Exa. e dos demais membros que a Comissão que estuda a "Atividade Negocial" do Projeto do Código Civil, em sua $1 .^{a}$ reunião, hoje realizada, deliberou o seguinte:

"Pelo Sr. Relator, Prof. Sampaio de Lacerda, foi sugerida a retirada, do Projeto, do Capítulo XXII, Livro I (artigos 866 a 889), motivado pelo fato de que os contratos bancários deveriam ser objeto de tratamento em lei especial.

Por isso, sugere a Comissão, por deliberação unânime, se re- 
meta a referida proposição à apreciação da Comissão de Direito das Obrigações, que é a competente para o exame dessa matéria".

Saudações.

(a) Desembargador Ary Florencio Guimarães, Presidente da Comissão

Ao Exm. ${ }^{\circ}$ Sr. Presidente da Comissão de Obrigações.

\section{COMISSÃO COISAS} sões:

A Comissão aprovou, por unanimidade, as seguintes conclu-

1. Em relação à proteção ao meio ambiente.

Foi recomendada a inclusão do seguinte artigo que encerraria o capítulo dos direitos de vizinhança:

"Art. O proprietário, ou possuidor de um prédio tem o direito de exigir do vizinho o cumprimento das normas de Direito Público relativas à vizinhança, à natureza da utilização e à localização dos imóveis, bem como das que preservem da polvição o ar e as águas, e da destruição a flora, a fauna, a paisagem e as belezas naturais".

Essa norma havia sido sugerida pelo próprio redator do Anteprojeto, Desembargador Ebert Chamoun, como corolário indispensável à atuação do princípio do art. 1.266, § 1., do projeto, segundo - qual o direito de propriedade deve ser exercido de modo a preservar o meio ambiente, pois através dela cada cidadão estará munido de um direito subjetivo que poderá invocar em seu favor, o que virá reforçar, consideravelmente, a proteção administrativa. Fôra ela aprovada no Simpósio realizado pela Associação dos Magistrados da Guanabara sobre "O homem e o meio ambiente", em 1971, e que foi comunicado ao Sr. Ministro da Justiça por ofício, em agosto daquele ano, e incluída no relatório do Brasil no Colóquio da União Internacional dos Magistrados, realizado no Rio de Janeiro, em setembro do mesmo ano, merecendo destaque como inovação muito interessante, no relatório geral. móvel.

2. Em relação à proteção do adquirente de boa-fé, de coisa

O art. 1.303 do projeto diz: "Feita por quem não seja proprietário, a tradição não alheia a propriedade, exceto se a coisa, ofere- 
cida ao público, em leilão ou estabelecimento comercial, for transferida em circunstâncias tais que, ao adquirente de boa-fé, como a qualquer pessoa, o alienante se afigurar dono".

Foi recomendada a seguinte alteração: "Feita por quem não seja proprietário, a tradição não alheia à propriedade, exceto se a coisa for transferida em circunstâncias tais que, ao adquirente de boafé, como a qualquer pessoa, o alienante se afigurar dono", assim como a inclusão de um parágrafo com a seguinte redação: "§ - Em se tratando, porém, de coisa furtada, a tradição não alheará a propriedade, devendo, no entanto, o proprietário pagar ao possuidor o preço por que a comprou, se a aquisição se deu em leilão público ou em estabelecimento comercial".

Entendeu a Comissão que o projeto procedera de modo muito louvável ao colocar a questão da proteção ao terceiro adquirente de boa-fé no local adequado, isto é, como restrição ao princípio de que a propriedade das coisas móveis só se transmite pela tradição feita por quem é dono, restrição imposta secularmente pela necessidade do comércio das coisas móveis e pela proteção à aparência do direito.

Considerou, porém, que era, por um lado, conveniente ampliar a proteção ao adquirente de boa-fé, além da hipótese da aquisição em leilão ou estabelecimento comercial e, por outro, mante: a exceção tradicional na matéria, consagrada no art. 521 do $\mathrm{C}$. Civil, relativa ao furto, hipótese em que a proteção do proprietário deve prevalecer sobre a do terceiro adquirente de boa-fé. Considerou, ainda, conveniente que, em relação à coisa furtada, fosse mantido, também, o tratamento dado pelo atual parágrafo único do art. 521 quando se tratasse de aquisição em estabelecimento comercial ou leilão público, hipótese em que o ônus da ação regressiva devia caber ao proprietário reivindicante.

3. Em relação à execução de imóvel hipotecado por crédito que não o do credor hipotecário.

Aprovou a Comissão a supressão do art. 1.508 do projeto e de seu parágrafo que reproduziram o art. 813 e seu parágrafo do C. Civil, dizendo: "Salvo o caso de insolvência do devedor, o credor da segunda hipoteca, embora vencida, não poderá executar o imóvel antes de vencida a primeira. Parágrafo único. Não se considera insolvente o devedor, por faltar ao pagamento das obrigações garantidas por hipotecas, posteriores à primeira".

Aprovou, ainda, a comissão a supressão do inciso VI do art. 
1.530 (reprodução do atual 849; VII) que previa a arrematação ou adjudicação como modo de extinção da hipoteca e, enfim, recomendou que o art. 1.532 tivesse a seguinte redação: "Não será válida a venda judicial de imóveis gravados por hipotecas devidamente inscritas, sem que tenham sido notificados judicialmente os respectivos credores hipotecários que não forem de qualquer modo partes na execução, a fim de que possam exercer direito de preferência no prazo de trinta dias; caso não o exerçam, a venda judicial não extinguirá as hipotecas".

A Comissão assim procedeu por considerar que, mantida em todo o seu rigor a realidade da hipoteca, que dela faz a mais segura garantia que se possa dar a um crédito, as possíveis vendas judiciais para execução de outros créditos em nada afetam o credor hipotecário cujo direito acompanha sempre o imóvel. Sendo assim, nenhuma razão para subordinar tais execuções ao vencimento da hipoteca. Foi eliminada, em conseqüência, a reprodução de normas que, já no C. Civil atual, suscitam dúvidas. A Comissão entendeu por fim que, na hipótese da insolvência, o vencimento antecipado de todos os créditos impunha solução específica que não cabia disciplinar dentro do instituto da hipoteca.

4..$^{\circ}$ Em relação à exceptio proprietatis, foi aprovada a sua inclusão no $\S 2 .^{\circ}$ do art. 1.249 que passaria a ter a seguinte redação: "Não obsta à manutenção ou reintegração na posse a alegação de propriedade, ou de direito sobre a coisa. Será, porém, deferida a posse a quem evidentemente tiver a propriedade, se, com base nesta, for ela disputada".

A Comissão entendeu que a inclusão da exceção de propriedade formulada nos termos da Súmula 487 do Egrégio Supremo Tribunal Federal corrigia os defeitos de redação do art. 505 do Código Civil e mantinha as vantagens do instituto, que contribui para a solução imediata de numerosas controvérsias possessórias.

5. Em relação à indenização de benfeitorias prestadas pelo reivindicante ao possuidor, a Comissão, atendendo às ponderações feitas pelo próprio redator do Anteprojeto, ilustre Desembargador Ebert Chamoun, aprovou para o art. 1.260 a seguinte redação: "O reivindicante obrigado a indenizar as benfeitorias tem 0 direito de optar entre o seu valor atual e o seu custo, quando se tratar de possuidor de má fé; tratando-se de possuidor de boa-fé, a indenização será sempre pelo valor atual". 
6. Anticrese. A Comissão pronunciou-se pela exclusão do instituto, pelos fundamentos expostos pelo redator do Anteprojeto, Desembargador Ebert Chamoun, em sua exposição de motivos.

Rio de Janeiro, 4 de dezembro de 1975.

\author{
(aa) Des. Agnano Monteiro Lopes \\ Presidente (T. J. - Pará) \\ Des. Basileu Ribeiro Filho \\ Relator, T. J. - (Rio de Janeiro) \\ Des. Homero Mafra \\ (Assoc. - Espirito Santo) \\ Des. Geraldo Gama Salles \\ (Assoc. Santa Catarina) \\ Juiz Edgar Winter \\ (Paraná) * \\ Juiz José Domingos Moledo Sartori \\ (II T. A. - do Rio de Janeiro)
}

\title{
5. ' COMISSÃO
}

\section{FAMILIA}

\section{I - Supressão do art. 1.543:}

Entendeu a Comissão que o dispositivo é obscuro, nada explicando a assertiva de tratar-se de direito absoluto, sob cujo conteúdo caberá ao juiz construir. Ou constitui mera recomendação, concernente à privacidade; ou pretende impedir, de modo cabal, a interferência na comunhão de vida estabelecida pelo casamento. Na primeira hipótese, não sendo direito cogente, não há razão para figurar no Código; na segunda, poderá levar ao absurdo de não evitar procedimentos ilícitos ou abusivos de um cônjuge contra outro.

\section{II - Casamento Religioso (arts. 1.546, 1.547, 1.552, IX):}

Será conveniente tornar explícitas as disposições que baralham o casamento religioso precedido de habilitação do que não o seja, conferindo ao primeiro eficácia, que ponha fim às manobras dos que dele se valem para uma simples tentativa de vida em comum e fraude de um contra outro consorte.

(*) Sem representação oficial. 
Alcança-se o objetivo com:

a) nova redação para o artigo 1.546:

"É obrigatório o registro civil do casamento religioso, precedido de habilitação feita nas condições da lei, devendo providenciá-lo o celebrante, para esse efeito equiparado a funcionário público, ou qualquer dos cônjuges";

b) supressão do atual parágrafo primeiro do art. 1.546 e sua substituição, aproveitando-se, parcialmente, o disposto no art. 1.547, com a seguinte redação:

"Na hipótese de falecimento de qualquer dos cônjuges, o registro civil do casamento religioso, precedido de habilitação na forma da lei, poderá ser promovido por seus descendentes ou ascendentes";

c) substituição do parágrafo $2 .^{\circ}$ do art. 1.546 , observando-se a redação que se segue:

"Será ineficaz o registro civil de casamento religioso se anteriormente à sua celebração qualquer dos consorciados houver contraído com outrem matrimônio civil";

d) inclusão de parágrafo $3 .^{\circ}$ ao art. 1.546 , nos seguintes termos:

"Efetuado o casamento religioso, com prévia habilitação civil, esta não perderá eficácia para os efeitos de futuro registro do casamento".

e) transformação, em disposição autônoma, que passaria a ser ○ art. 1.547, do atual parágrafo $3 .^{\circ}$ do art. 1.546;

f) alteração do item IX do art. 1.552, impedindo-se o casamento de pessoa que tenha contraído matrimônio religioso, precedido de habilitação:

“Art 1.552

IX. A pessoa que tenha com outrem contraído matrimônio religioso precedido de habilitação, nos termos da lei civil, ainda que não requerida a inscrição desse casamento no registro civil.

\section{III - Art. 1.550 - Supressão Parcial:}

O art. 1550 reproduz o teor do art. 188 do Código de 1916, à luz do qual se cristalizou a jurisprudência, no entendimento da voluntariedade do recurso ali previsto. A recorribilidade das decisões definitivas é princípio firmado na sistemática processual, sen- 
do dispensável a manutenção da parte final do dispositivo, que prevê "recurso para instância superior".

\section{IV - Supressão do item VIII do art. 1.552}

Trata-se de reiteração do impedimento do art. 183, VII, do Código de 1916, de cuja aplicação não se tem conhecimento.

O entendimento da doutrina é pela necessidade de sentença condenatória, e há, no âmbito do Direito Penal, indiscutível decadência da repressão do adultério.

Eventualmente suprimida a figura penal do adultério, restará inteiramente comprometido o impedimento matrimonial fundado na ientença condenatória do adúltero e de seu co-réu.

Por outro lado, o próprio impedimento matrimonial assim configurado é de conveniência discutível na doutrina, certo que força a manutenção do concubinato entre os adúlteros, mesmo depois da morte do cônjuge enganado.

\section{V - Art. 1.588 - Supressão Parcial}

Deve-se excluir a legitimidade dos herdeiros do incapaz para a ação anulatória do seu casamento, sobretudo porque, dentre eles, inclui $\circ$ Projeto os colaterais até $\circ 4 .^{\circ}$ grau, que agiriam sob inspiração quase exclusiva de interesses pecuniários na sucessão, suprimindo-se, portanto, do dispositivo, as expressões "pelos herdeiros".

\section{VI - Legiłimidade dos filhos nascidos do małrimônio nulo (não putativo)}

A Comissão reconhece a tendência que se manifesta nas legislações mais atualizadas, Código Civil espanhol, art. 69; Código Civil português, art. 1802; Código Civil suíço, art. 133, I, no sentido de resguardar a condição de legítimo, irrogada ao filho nascido do matrimônio nulo, ou anulável, independente de qualquer perquirição a respeito da boa-fé uniaterlal ou recíproca dos conjuges e recomenda a revisão do art. 1.595 do Projeto.

\section{VII - Desquite Litigioso}

Propõe a Comissão a integração, em um só, dos artigos 1.609 e 1.610, com aditamento de mais uma hipótese de desquite, manrido o parágrafo único do art. 1.609, com nova redação.

Os casos especificados nem sempre importam na impossibilidade de vida em comum, e esta pode ocorrer sem que se verifi- 
que qualquer daqueles, conforme anterior jurisprudência sob a escoteira sustentação do saudoso Min. Philadelpho de Azevedo.

Suprimido o art. 1.610, ○ 1.609 teria a seguinte redação:

"Qualquer dos cônjuges poderá propor ação de desquite, ocorrendo algum dos seguintes motivos:

1 - Adultério.

II - Tentativa de morte.

III - Sevícia ou injúria grave.

IV - Abandono voluntário do lar conjugal, durante um ano contínuo.

V - Condenação por crime infamante.

VI - Conduta desonrosa.

VII - Impossibilidade de vida em comum por motivos graves.

\section{VIII - Art. 1615 - Modificação}

Pareceu à Comissão muita boa a ressalva constante da segunda parte do art. 1.615 do Projeto. Sugere, no entanto, que se assegure igual faculdade à mulher, quando nada a respeito se dispuser no desquite por mútuo consentimento. $O$ artigo ficaria assim redigido:

"A mulher condenada na ação de desquite perde o direito a usar o nome do marido. Se condenado o marido, ou se nada se dispuser no desquite por mútuo consentimento, assiste à mulher o direito de retomar seu nome de solteira".

\section{IX - Alimentos devidos ao cônjuge desquitado}

Tal como está redigido, o artigo 1.763 do Projeto permite que o cônjuge desquitado, beneficiário de alimentos, possa recuperar o direito de reclamá-los, se o perdeu em virtude de concubinato ou procedimento indigno, uma vez rompido aquêle ou cessado este.

A Comissão acolhe a sugestão para reformulação do artigo, esteiada nos fundamentos do Prof. Simão Benjó ("Aspectos da Obrigação Alimentar", in "Revista de Direito da Procuradoria Geral da Justiça", vol. I, pág. 36), propondo a seguinte redação:

"O cônjuge desquitado perde o direito a alimentos se viver em concubinato, ou tiver procedimento indigno". 


\section{$X$ - Posse e guarda do filho reconhecido}

Será melhor manter o disposto na lei n. ${ }^{\circ} 5.582 / 70$, que alterou o art. 16 do Decreto-lei n. ${ }^{\circ} 3.200 / 41$. Pelo art. 1.654 do Projeto, não havendo acordo, tornar-se-á exigível decisão jud'cial, que, à luz da lei vigente, só será necessária se advier prejuízo ao menor que estiver sob poder da mãe.

\section{XI - Direção da Sociedade Conjugal}

Fundada no princípio de igualdade entre homem e mulher, a Comissão acolhe a sugestão para nova redação do art. 1.603 e seu parágrafo, nos seguintes termos:

Art. 1.603. A direção da sociedade conjugal cabe ao marido, em conjunto com a mulher, sempre no interessa do casal e dos filhos.

Parágrafo único. As questões essenciais serão decididas em comum. Havendo divergência, poderão os cônjuges recorrer à autoridade do juiz, em conjunto ou separadamente.

XII - Posse e guarda dos filhos pelo viúvo, ou viúva, que contrai novas núpcias

O art. 1.621 é unilateral porque só dispõe sobre a mãe. Igual solução deve prevalecer em se tratando do pai que venha a contrair novas núpcias.

Sugere-se a seguinte redação:

"O pai, ou a mãe, que contrair novas núpcias não perde o direito de ter consigo os filhos do leito anterior, que só lhe poderão ser retirados, por ordem judicial, provado que qualquer deles, o padastro ou a madastra não os tratam convenientemente".

\section{XIII - Art. 1.609, parágrafo único - Substituição processual e não representação}

A possibilidade de ser a ação de desquite proposta por ascendente ou irmão do cônjuge, incapaz de exercê-la, configura uma hipótese de substituição processual, motivo por que, no dispositivo, a palavra "representado" deverá ser alterada para "substituído", corrigindo-se equívoco do Código de 1916 (art. 316, parágrafo único). 


\title{
XIV - Imutabilidade do regime de bens
}

A Comissão verificou que o projeto não cuidou expressamente, como convém, da imutabilidade do regime de bens, e sugere que DS arts. 1.694 e 1.695 sejam transformados num só dispositivo legal, de n. ${ }^{\circ}$ 1.694, com o parágrafo único correspondente ao art. 1.695. Seria dada ao art. 1.695 a mesma redação do art. 230 do Código Civil de 1916.

\section{XV - Regime da separação obrigatória e comunicação dos aquestos}

A Comissão entende que, no regime da separação obrigatória, deve prevalecer a comunicação dos aquestos (Súmula 377), suprimindo-se, assim, a parte final do art. 1.696 do Projeto, com dois pontos na palavra casamento, a despeito da doutrina, que está divorciada da realidade.

\section{XVI - Adoção}

A Comissão recomenda sejam levados em consideração os comentários feitos pelo Des. Bulhões Carvalho em sua obra "Emendas ao Projeto 643 do Novo Código Civil”, págs. 81 a 96, no sentido de melhorar o tratamento legislativo do instituto.

Especialmente, deve ser suprimido o parágrafo $3 .^{\circ}$ do artigo 1.669 e retificado o erro material da parte final do art. 1.672, que se refere, em verdade, ao art. 1.886 .

\author{
(aa) Des. João de Oliveira e Silva \\ Presidente - (T. J. Alagoas) \\ Juiz Onurb Couto Bruno \\ Relator - (Rio de Janeiro) \\ Des. Domingos Sávio Brandão Lima \\ (T. J. - Mato Grosso) \\ Des. Bruno Afonso André \\ (Associação - São Paulo) \\ Juiz Manuel Cândido Filho \\ (Associação - Sergipe) \\ Juíza Maria Rita Soares de Andrade \\ (Rio de Janeiro)
}




\author{
Juiz Danilo Antonio Barreto Accioly \\ (Associação - Alagoas) \\ Juiz Sebastião Rios Corrêa \\ (Juiz Federal - D. F. - Associação - 1. ${ }^{a}$ \\ Instância)
}

\title{
Prof. e Promotor Público Simão Isaac Benjó \\ (Rio de Janeiro)
}

\section{6.` COMISSÃO}

\section{SUCESSÕES}

Instalada a Comissão, composta dos Desembargadores Aderbal Gonçalves (Ba), Ribeiro do Valle (MG) e Costa Manso (SP) e dos Juízes Augusto Tiezze (RJ) e Carlos Gualda, este último relator, funcionando como secretária d. Maria Lúcia Farah de Mesquita, foi eleito por unanimidade o Des. Aderbal Gonçalves para Presidente. Convidado para participar dos debates esteve presente a todos os trabalhos o ilustre Prof. Torquato Castro, que prestou excelente colaboração.

Examinadas e discutidas as diversas proposições apresentadas, foram em seguida aprovadas as seguintes sugestões:

\section{1. ${ }^{\text {a }}$ Sugestão:}

Excluir o Capítulo X do Título III - Livro IV, referente à deserdação, por se tratar de instituto odioso, cujas finalidades já estão preenchidas no Capítulo V, arts. 1861 a 1865 do Título I.

Vencidos o Des. Costa Manso e o Juiz Benito Augusto Tiezzi.

\section{2. ${ }^{a}$ Sugestão:}

Na hipótese, porém, de ser mantida a deserdação, deve acrescentar-se ao art. 2.011: "..., obseivada a regra do art. 1.863 e seu $\S$ único".

Passaria, pois, o artigo a ter a seguinte redação: "Os herdeiros necessários podem ser privados de sua legítima, ou deserdados, em todos os casos em que podem ser excluídos da sucessão, observada a regra do art. 1.863 e seu parágrafo único". Ou seja, o deserdado não terá direito ao usufruto ou à administração dos bens que aos seus sucessores couberem na herança, evitando-se deste modo dúvida, em face da redação atual do artigo. 


\section{3. ` Sugestão:}

Acrescentar ao art. 2.014: "... judicialmente reconhecida".

"A deserdação só pode ser ordenada em testamento, com expressa declaração de causa judicialmente reconhecida".

O acréscimo visa a evitar dúvida quanto à necessidade, sempre, da sentença declaratória da deserdação.

\section{4. ${ }^{a}$ Sugestão:}

Substituir no parágrafo único do art. 1.873 a expressão "da introdução" por "do ajuizamento".

Passa, por conseguinte, o parágrafo à seguinte redação: "A partir do ajuizamento da lide, a responsabilidade do possuidor se há de aferir pelas regras concernentes à posse de má fé e à mora".

Visou-se, com isso, dar mais precisão ao parágrafo.

\section{5. ' Sugestão:}

Novo sentido e redação ao art. 1.889 e seu parágrafo único: "Pode o testador estabelecer cláusula de inalienabilidade, incomunicabilidade ou impenhorabilidade quanto à legítima, ou a conversão dos bens que a constituem em outros de outra espécie".

Parágrafo único. Não havendo motivo justo, pode a cláusula ser invalidada por sentença provocada pelo herdeiro ou legatário".

Visou-se, com a alteração, evitar constrangimento ao testador ou aos seus parentes próximos em torno da causa ou motivo jusfificativo da cláusula e, ao mesmo tempo, possibilitou-se ao interessado a oportunidade de demonstrar a sem razão do vínculo estabelecido.

\section{6." Sugestão:}

Suprima-se o requisito constante da parte final do art. 1.879: "... se for ascendente dos herdeiros com que concorrer".

Pretende-se, com isso, suprimir a distinção que surge no art. seguinte em relação a filhos legítimos e ilegítimos.

Em conseqüência, 


\section{7.' Sugestão:}

Suprima-se integralmente o art. 1.880.

\section{8. ` Sugestão:}

No art. 1.885 substitua-se a palavra legitimados por ilegítimos.

Harmoniza-se, assim, o texto com a sistemática do Projeto e com s legislação vigente.

\section{Sugestão:}

O parágrafo único do art. 1.886 passa a ser o seguinte:

"Em se tratando de adoção restrita, se o adotado deixar descendentes legítimos ou ilegítimos, ascendentes ou cônjuge, o adotante não será chamado à successão".

Pretende-se, com a alteração proposta, atribuir ao adotante 0 mesmo tratamento dispensado ao adotado no art. 1.885 .

\section{0.' Sugestão:}

O parágrafo único do art. 2.078 passa a ser o seguinte:

"Extingue-se em dois (2) anos o direito de anular a partilha (art. 169)".

Ampliou-se o prazo, que passa a coincidir com o da ação rescisória e fez-se remissão ao art. 169 para evitar dúvida quanto à nulidade absoluta.

\section{1. ${ }^{\text {a Sugestão: }}$}

O art. 2.037 passa a ter dois parágrafos, mantido como primeiro o atual parágrafo único e acrescenta-se o parágrafo segundo com a seguinte redação:

"§ 2. $\quad$ No caso de as dívidas absorverem todo o acervo, o prêmio será arbitrado pelo Juiz, consoante apreciação equitativa, e o seu quantum sairá do monte, como despesas judiciais".

Resguarda-se, assim, o princípio de que o trabalho deve ser remunerado, tanto mais quanto indispensável.

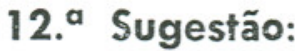

Acrescentar ao art. 1.847 o inciso: 